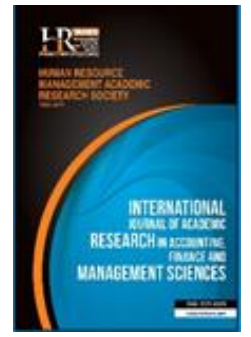

International Journal of Academic Research in Accounting, Finance and Management Sciences

Vol. 8, No.2, April 2018, pp. 155-163

E-ISSN: 2225-8329, P-ISSN: 2308-0337

(c) 2018 HRMARS

www.hrmars.com

To cite this article: Bhilawa, L., Kautsar, A. (2018). The Determinants of Relationship Between Budgetary Participation and Budgetary Slack, International Journal of Academic Research in Accounting, Finance and Management Sciences 8 (2): 155-163.

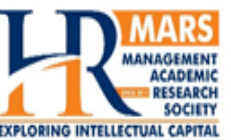

http://dx.doi.org/10.6007/IJARAFMS/v8-i2/4240 (DOI: 10.6007/IJARAFMS/v8-i2/4240)

\title{
The Determinants of Relationship Between Budgetary Participation and Budgetary Slack
}

\author{
Loggar BHILAWA ${ }^{1}$, Achmad KAUTSAR ${ }^{2}$ \\ ${ }^{1}$ Departement of Accounting, Faculty of Economics, Universitas Negeri Surabaya, Indonesia, \\ ${ }^{1}$ E-mail: loggarbhilawa@unesa.ac.id \\ ${ }^{2}$ Departement of Management, Faculty of Economics, Universitas Negeri Surabaya, Indonesia, \\ ${ }^{2}$ E-mail: achmadkautsar@unesa.ac.id
}

\begin{abstract}
The objective of this study is to test the influence of budgetary participation on budgetary slack, as well as to test whether or not information asymmetry, job relevant information, goal orientation, organizational commitment, and innovation perception are the moderation variables that affect the relation between budgetary participation and budgetary slack. Sample in this research is the managers in all Faculty of " $X$ " State University in Indonesia who comprised of the head of department and the head of study program in total number 87 manager. Analysis is done through descriptive, instruments of validity and reliability tests, classical assumption test, and interaction regression analysis. Research findings showed that budgetary participation negatively affected budgetary slack. Higher participation level in the budgetary process will decrease the tendency of budgetary slack from happening. Information asymmetry, goal orientation, and innovative perception moderate the relation between budgetary participation and budgetary slack. Job relevant information and organizational commitment do not have any influence on the relation between budgetary participation and budgetary slack. This article gives contribution to the inconsistencies in many previous studies about the relation between budgetary participation and budgetary slack by adding other variables that are suitable with the organizational characteristics of public sector related to work behavior and work culture especially in state university and in emerging country scenario.
\end{abstract}

Key words

Budgetary participation, budgetary slack, information Asymetri, job relevant information

Received: 18 May 2018 (c) The Authors 2018

Revised: 06 Jun 2018

Published by Human Resource Management Academic Research Society (www.hrmars.com)

Accepted: 20 Jun 2018 This article is published under the Creative Commons Attribution (CC BY 4.0) license. Anyone may Published Online: 30 Jun 2018 reproduce, distribute, translate and create derivative works of this article (for both commercial and noncommercial purposes), subject to full attribution to the original publication and authors. The full terms of this license may be seen at: http://creativecommons.org/licences/by/4.0/legalcode

\section{Introduction}

The commitment of the Government of Indonesia toward Indonesian education is embodied by giving 20\% budget of total State Income and Expenditure Budget (APBN) in number of IDR 207 billions (or 10.350 millionsPound sterling) from the total of Indonesian APBN of IDR 1,037 billions in 2009 (Santoso, 2014). Education has become the priority for public service provided by the government. Given with such huge amount of budget thus a very careful planning necessarily be taken so the budget can be right on target and can be enjoyed by all Indonesian children.

This budget has to be used to administer education, to improve educational facilities and infrastructures, and to grant scholarships to top achievers and poor students. In order to operate the organizational activities in a more effective and efficient ways thus a planning and controlling tools are required, namely a budget which constitutes the element of management control system (Schiff and Lewin, 
1970). A good financial planning for people must be carried out in precise and correct ways. People or parties who involved in the budgetary process are required to have competence and dedication so that the granted fund can be allocated correctly and appropriately for each activity. A budget has to be well design, effectively and efficiently implemented, adequately monitored and its performsnce evaluated (Oniore, 2014).

The budgetary making process has direct impact on the human behavior (Siegel and Marconi, 1989), especially for those who directly involved in that budgetary making process. The most frequent problem found from the involvement of subordinates or budget implementer in budget making process is the presence of budgetary slack, namely an attempt done by subordinate or budget managers to facilitate the achievement of budgetary target by raising the cost or reducing the revenue than it should be (Merchant, 1981; Young, 1985; Lukka, 1988).

The presence of budgetary slack can be triggered by several causes, among others, the existence of rigidity or inflexibility in controlling the budget. Management performance will be measured based on the budgetary achievement. As consequence, higher career paths, bonuses, and salaries will increase if they are able to meet the budget target. Otherwise, for managers who cannot meet the target, he or she will face the pressures from upper management, such as in form of losing trust, losing bonuses, and even losing jobs (Merchant and Manzoni, 1989). In this kind of condition, those subordinates will seek ways to protect themselves from the risks of unable to meet the predetermined budget target (Schiff and Lewin, 1970; Onsi, 1973; Lukka, 1988). One of ways to do so is by doing budgetary slacking.

\section{Theoretical Framework and Hypothesis Development}

\subsection{Budget}

Freeman (2003) stated that budget is a process of allocating resources owned and done by public sector organizations for unlimited demands. Siegel and Marconi (1989) stated that budget is managerial plans to express its actions in financial forms. If the budgetary process is based on the predetermined longterm activity plan, actually this budget will not take any organization anywhere. Budget comprises the element in the management control system which has function as the controlling and planning tools so that subordinates or managers able to perform organizational activities in more effective and efficient ways (Schiff and Lewin, 1970; Brownell, 1983; Dunk, 1993). According to Kenis (1979), budget is not merely a financial plan which sets the income and cost, as well as a center of accountability in any organization, but also a means for the highest decision making (top management) to coordinate, control, communicate, evaluate, and motivate their subordinates.

\subsection{Budgetary Participation and Budgetary Slack}

Budgetary participation provides and produces bigger opportunities for subordinates or budget managers to create budgetary slack if they have more information than their superiors (Baiman and Evans, 1983; Lukka, 1988; Dunk, 1993; Shields and Young, 1993). Studies about the influence of budgetary participation on budgetary slack still show inconsistencies in their results. Onsi (1973), Fitri (2004), Merchant (1981), and Pratiwi (2011) stated that budgetary slack is decreasing since the participation is directed to positive communication. However, (Young, 1985; Dunk, 1993; Ikhsan and Ane, 2007; Kartika, 2010) stated that participation can conversely increase budgetary slack.

$H_{1}$. Budgetary participation negatively affects budgetary slack.

\subsection{Information Asymmetry}

It is a condition where one party has more knowledge than other parties related to something. Dunk (1993) explained that information asymmetry occurred when within an organizational unit; subordinates have more information than their superiors. Anthony and Govindarajan (2007) stated that the theory of agency underlies the presence of information asymmetry, namely the agent (subordinate) is given with authority by the principal (superior) to manage or organize a company or an organization. Studies by Merchant (1981) and Young (1985) showed that subordinates who conceal the relevant information in the budgetary process will likely to raise the budgetary slack. Information asymmetry happened due to the 
imbalance of information ownership between superior or the budget power holder and subordinates or budget managers. It occurs because subordinates or budget managers are more directly involved in company's daily operations compared to their superiors or budget power holder.

$H_{2}$. Information asymmetry affects the relation between budgetary participation and budgetary slack.

\subsection{Job Relevant Information}

Job Relevant Information is defined as an information that facilitates or mediates positive relation among decision making processes related to a certain task in a certain organization (Kren, 1992). Job relevant information helps subordinates or budget managers to increase the options of a decision through an information that well succeed (Baiman and Evans, 1983). Subordinates of budget managers who take part in the budgetary process will produce private information, in which superiors or budget power holders have not had that information yet, hence it will increase the understanding between superior and subordinates in budgetary process (Merchant, 1981; Chow et al, 1988; Nouri and Parker, 1998).

$H_{3}$. Job relevant information (JRI) affects the relation between budgetary participation and budgetary slack.

\subsection{Goal Orientation}

According to Chai et al (2012), goal orientationis related to why and how individuals or subordinates try to achieve more than to meet the stand ards. Goal orientation shows individual's working mental in interpreting and responding certain achievement situation (Yeo and Neal, 2004). Related to budgetary, goal orientation has been a strong will or determination to meet the objectives of certain budget and to improve them over time in order to be better (Chong and Chong, 2002). Budgetary system is not only limited by financial control, but also having influence on the behavioral aspect of subordinates or budget managers regarding to budgetary process. Subordinates or budget managers in the budgetary participation system have direct involvement within the budgetary process. Accordingly, the goal orientation is going to be achieved by an organization can have a conflict with the goal orientation of its each individuals or groups.

$H_{4 .}$ Goal orientation affects the relation between budgetary participation and budgetary slack.

\subsection{Organizational Commitment}

According to Wiener (1982) and Curtis (2001), organizational commitment is defined as an inner drive of individual's desires in doing something that can support the successfulness of an organization where the individual works in accordance with the objectives and that prioritize more on organizational interests. Organizational commitment is defined as a strong will to become a member of a group and as a high hard work for certain organization (Davis and Luthans, 1980). According to Durkin and Bennett (1999), organizational commitment is individual's strong and closely feeling or sensetoward the organizational values and objectives regarding to individual's roles in achieving those objectives and values. A strong organizational commitment will boost individuals to work hard in achieving the organizational objectives budgetary participation will produce budgetary sufficiency and later on will influence their performance (Nouri and Parker, 1998).

$H_{5}$. Organizational commitment affects the relation between budgetary participation and budgetary slack.

\subsection{Innovative Perception}

Innovative perception is defined as a picture of the extent of subordinates or budget managers consider themselves as innovative person. Subordinates or budget managers will be more motivated to perform their job when their ideas are appreciated (Quirinet al., 2001; Subramaniam and Ashkansy, 2001). Those are very important because the budgetary operation in University is started from the lowest working unit, thereby inputs from subordinates or budget managers will be very beneficial during the budgetary process. By the presence of budgetary participation thus will foster innovative perceptions on the part of managers. By getting involved in the budgetary process will foster managers' innovative perceptions. 
Subordinates of budget managers who think that their ideas are appreciated by the organization they are working to will successfully foster higher innovations.

$H_{6}$. Innovative perception affects the relation between budgetary participation and budgetary slack.

\section{Methodology of research}

Sample in this research is the managers in all Faculty of a " $X$ " State University in Indonesia which consisted of the Head of Study Program in total number of 104 people. Sample is taken by using purposive sampling technique, namely sample is taken for particular purpose in number of 87 respondents who returned the questionnaires. Those or managers were taken as sample because the researcher considered them the best sources to give information needed in the study. Data used in this research is in form of primary data. This primary data is obtained and collected directly from the study site through questionnaires.

\subsection{Measurement}

BudgetaryParticipation. Budget is short-term work plan expressed quantitatively and measured in monetary units in which its making is conformed with the predetermined long-term work plan (Mulyadi, 2001). The budgetary process involves subordinates or budget managers. It is believed that this is able to increase the sense of control and involvement among the subordinates or budget managers (Chong and Chong, 2002). The measurement of influence and involvement of individual subordinate or budget manager within the budgetary process is done by using the instrument developed by Milani (1975). This instrument has 6 items of questions with scores in form of scale from 1 to 7 . One mean highly disagree and seven means highly agree.

Budgetary Slack.Budgetary slack is the difference between the reported budget and the budget based on the real estimationso that the target put on the subordinates can be easily achieved (Anthony and Govindarajan, 2007). Young (1985) outlined that budgetary slack is a particular action taken by subordinates to reduce their productive capabilities when they are given with opportunity to set their working stand ards. Items used in measuring the budgetary slack adapt questions that had been used by Dunk (1993) which consisted of six items of questions. Scale is used, one shows the answer of highly disagree, and seven means highly agree.

Information Asymmetry. Kren et al. (1988) explained that information asymmetry is the difference of information ownership between superiors and subordinates related to relevant budge information. Usually superiors have less information than their subordinates. A questionnaire developed by Dunk (1993) is used to measure this variable. This variable measurement consists of 6 (six) questions by using Likert scale of one to seven. The scale scores showed the answer for each item in which the options would be one is for highly disagree and seven is highly agree.

Job Relevant Information. In this research, job relevant information (JRI) is identified as one of information that helped managers to make decision effectively through any well-informed efforts (Kren, 1992). To measure this variable thus the questionnaire developed by Kren (1992) is employed here. This variable measurement used 3 (three) questions in Likert scale of one to seven. Those three questions comprised the understanding about the tasks have to be performed in that particular post, information availability, and ability to gain strategic information. Scale scores showed each answer for each item, in which the answer of one meant highly disagree and seven meant highly agree.

Goal Orientation. The goal orientation in this study is the moderating variable. This variable is developed from previous studies (Julnes and Holzer, 2001). This variable consists of indicators covering the following matters, namely communicating strategy(s) in order to meet or achieve the targets, agreement that during the implementation of organizational missions it also encourages efficiency, the make use of applications related to decision making and work outputs in accordance with the objectives wish to meet. Every question is measured by using 7 point Likert scale, in which the answer options will be one for highly disagree and seven for highly agree.

Organizational commitment. The organizational commitment in this study is a moderating variable. This variable adapted the study by Mowday et al. (1979) which consisted of nine items of questions. The answers for questions related to organizational commitment were made in Likert scale with 1 to 7 point 
range. The scale scores showed the score for answer of every item's question, in which the answer option of one is for highly disagree and seven for highly agree.

Innovative perception. Manager's innovative perception is measured by using instrument of questionnaire adapted from the study of O'Reilly et al. (1991) as well as Windsor and Ashkanasy (1995). This question list consisted of six items. Respondents were asked to show to what extent they considered themselves as innovative individuals. Answer alternatives used the Likert scale of one (the lowest) to seven (the highest). When respondent answered one meant that absolutely no while five showed the highest level of innovativeness.

\subsection{Analysis}

This study used the interaction regression analysis or frequently called as Moderated Regression Analysis (MRA). It is a special application of multiple linear regression in which the regression equation contains interaction elements (Ghozali, 2006; Liana, 2009). Regression Analysis (MRA) is used to determine the interaction influence between budgetary participation, information asymmetry, job relevant information (JRI), goal orientation, organizational commitment, and innovative perception and the budgetary slack (Hartmann and Moers, 1999).

To answer above hypothesis thus the following equation is used:

$B S=\alpha+\beta_{1} B P+\beta_{2} A I+\beta_{3} J R I+\beta_{4} O C+\beta_{5} I P+\beta_{6} G O+\beta_{7} B P * A I+\beta_{8} B P * J R I+\beta_{9} B P * O C+\beta_{9} B P * I P+\beta_{10} B P * G O$ e (1)

Where:

BS is Budgetary Slack, BP is the Budgetary Participation, Al is the Asymmetri Information, JRI is the Job Relevant Information, OC is the Organizational Commitment, IP is the Innovation Perception and GO is the Goal Orientation.

Since multivariate regression is used to test the hypotheses, assumptions of normality, multicollinearity and homoscedasticity are also tested and the results are no problem with normality, multicollinearity and homoscedasticity ${ }^{1}$. The normality test is conducted using skewness, kurtosis and Kolmogorov-Smirnov Z. While the Pearson correlation matrix and variance inflator factor (VIF) are used to test the multicollinearity assumption. Moderated Regression analysis test is adopted to test the hypotheses.

\section{Results}

Table 1. Moderated Regression analysis

\begin{tabular}{lrr}
\hline & \multicolumn{2}{c}{ Unstandardized Coefficients } \\
\cline { 2 - 3 } & \multicolumn{1}{c}{ S } &, 206 \\
\hline (Constant) & 97,456 &, 158 \\
Budgetary Participation & $-3,434$ &, $000^{*}$ \\
Assymetri Information & 33,243 &, $005^{*}$ \\
Job Relevant Information & 1,062 &, $091^{* * *}$ \\
Goal Orientation & $-3,016$ &, $000^{*}$ \\
Organizational Commitment & $-13,386$ &, 325 \\
Innovative Perception &,- 128 &, $000^{*}$ \\
Budgetary Participation*Assymetri Information &,- 947 \\
Budgetary Participation*Job Relevant Information &,- 023 &, $062^{* * *}$ \\
Budgetary Participation*Organizational Commitment &,- 007 &, 596 \\
Budgetary Participation* Innovative Perception &, 116 &, $017^{* *}$ \\
Budgetary Participation* Goal Orientation &, 375 &, $000^{*}$
\end{tabular}

Legend: Dependent Variable: Budgetary Slack, *highly significant ${ }^{* *}$ significant $* * *$ moderate significant, $\mathrm{R}$ square: 0,810, Adj. R square: 0,781, F: 28,630, Sig.F: 0,000

\footnotetext{
${ }^{1}$ Table not shown for brevity
} 
Table 1 showed the results from the regression model test. The adjusted $R^{2}$ value from this model is 78.1\%. This means that budgetary slack of $78.1 \%$ can be explained by the budgetary participation, information asymmetry, job relevant information (JRI), goal orientation, organizational commitment, and innovative perception, also this model include the interaction between budgetary participation and information asymmetry (BP* $\mathrm{Al})$, interaction between budgetary participation and job relevant information $(\mathrm{BP} * \mathrm{JRI})$, interaction between budgetary participation and goal orientation (BP*GO), interaction between budgetary participation and organizational commitment (BP*OC), and interaction between budgetary participation and innovative perception (BP*IP).

The result of F-value test showed $F$ value of 28.630 with a significance of 0.000 . Accordingly, it can be concluded that budgetary participation, information asymmetry, job relevant information, goal orientation, organizational commitment, and innovative perception, also include the interaction between budgetary participation and information asymmetry, interaction between budgetary participation and job relevant information, interaction between budgetary participation and goal orientation, interaction between budgetary participation and organizational commitment, and interaction between budgetary participation and innovative perception simultaneously affected the budgetary slack.

\subsection{Hypothesis Testing}

Regression t-value has an objective to identify the influence of each independent variable on dependent variable. The result of $t$-value showed that the variable of budgetary participation had regression coefficient value of -3.434 , higher that $t$-table of $( \pm 1.9876)$ with a significance of 0.158 . It therefore can be drawn a conclusion that budgetary participation negatively and significantly affected the budgetary slack, which means that higher budgetary participation, lower budgetary slack. As a result, the first hypothesis is accepted.

Second hypothesis stated that information asymmetry affects the relation between budgetary participation and budgetary slack. The result of multiple regression analysis obtained the $t$-count value for the variable of interaction between budgetary participation and information asymmetry (BP*Al) of -0.947 , lower than $\mathrm{t}$-table of $( \pm 1.9876)$ and a significance of 0.000 , which is lower than $5 \%$. Likewise, the second hypothesis, information asymmetry affects the relation between budgetary participation and budgetary slack, is accepted.

The third hypothesis stated that job relevant information (JRI) affects the relation between budgetary participation and budgetary slack. The result of multiple regression analysis obtained the t-count value for the variable of interaction between budgetary participation and job relevant information (BP*JRI) of -0.023 , lower than $t$-table of $( \pm 1.9876)$ and a significance of 0.780 , which is higher than $5 \%$. Therefore, the third hypothesis, job relevant information affects the relation between budgetary participation and budgetary slack, is rejected.

The fourth hypothesis stated that goal orientation affects the relation between budgetary participation and budgetary slack. The result of multiple regression analysis obtained the t-count value for the variable of interaction between budgetary participation and goal orientation (BP*GO) of 0.375 , lower than t-table of ( \pm 1.9876$)$ and a significance of 0.000 , which is lower than $5 \%$. Consequently, the fourth hypothesis, goal orientation affects the relation between budgetary participation and budgetary slack, is accepted.

The fifth hypothesis stated that organizational commitment affects the relation between budgetary participation and budgetary slack. The result of multiple regression analysis obtained the t-count value for the variable of interaction between budgetary participation and organizational commitment (BP*OC) of .007 , lower than $t$-table of $( \pm 1.9876)$ and a significance of 0.596 , which is higher than $5 \%$. As a result, the fifth hypothesis, organizational commitment affects the relation between budgetary participation and budgetary slack, is rejected or denied. This result is in accordance with Owusu et al (2014).

The sixth hypothesis stated that innovative perception affects the relation between budgetary participation and budgetary slack. The result of multiple regression analysis obtained the t-count value for the variable of interaction between budgetary participation and innovative perception (BP*IP) of 0.116 , lower than $t$-table of $( \pm 1.9876)$ and a significance of 0.017 , which is lower than $5 \%$. Therefore, the sixth 
hypothesis, innovative perception affects the relation between budgetary participation and budgetary slack, is accepted.

\section{Conclusions}

This research have an objective to test the influence of budgetary participation on budgetary slack with information asymmetry, job relevant information, goal orientation, organizational commitment, and innovative perception as moderating variables. This research is a survey study with collected data obtained from questionnaires. Data analysis in this study used moderating regression analysis.

The results identified several findings, namely the result of first hypothesis testing showed that budgetary participation negatively affects the budgetary slack, which means that budgetary participation decrease the number of budgetary slack in the " $X$ " State University in Indonesia. Moreover, a conclusion also can be drawn that information asymmetry is a variable that moderated the influence of budgetary participation on budgetary slack. Budgetary participation will decrease if the information asymmetry increases.

The third hypothesis indicated that job relevant information had no influence on the relation between budgetary participation and budgetary slack thus, to put it in another way, job relevant information is not moderating variable in the relation between budgetary participation and budgetary slack.

The fourth hypothesis showed that goal orientation had influence to strengthen or weaken the relation between budgetary participation and budgetary slack. This finding indicated that individuals who take part in budgetary process will try best to meet or achieve the organizational objectives and embody the ideal budgetary objectives because those can reduce the tendency of budgetary slack.

The fifth hypothesis indicated that organizational commitment had no influence on the relation between budgetary participation and budgetary slack. It can be interpreted that the budget managers in the " $X$ " State University in Indonesia prioritize more on individual or group interests as a whole. The results from fifth hypothesis testing showed that innovative perception had influence on the relation between budgetary participation and budgetary slack, hence it can be said that innovative perception is one of moderation variables.

\section{References}

1. Anthony, R. N., \& Govindarajan, V. (2007). Sistem Pengendalian Manajemen. Jakarta: Salemba Empat.

2. Baiman, S., \& Evans, J. H. (1983). Pre-Decision Information and Participative Management Control Systems. Journal of Accounting Research, 21(2), 371-396.

3. Brownell, P. (1983). The Motivational Impact of Management-By-Exception in a Budgetary Context. Journal of Accounting Research, 21(2), 456-473.

4. Chai, J., Zhao, G., \& Babin, B. J. (2012). An Empirical Study on the Impact of Two Types of Goal Orientation and Salesperson Perceived Obsolescence on Adaptive Selling. Journal of Personal Selling \& Sales Management, XXXII(2), 261-273.

5. Chong, V. K., \& Chong, K. M. (2002a). Budget Goal Commitment and Informational Effects of Budget Participation on Performance: A Structural Equation Modeling Approach. Behavioral Research in Accounting, 14(1), 65-86. Retrieved from http://aaajournals.org/doi/abs/10.2308/bria.2002.14.1.65

6. Chong, V. K., \& Chong, K. M. (2002b). Budget Goal Commitment and Informational Effects of Budget Participation on Performance: A Structural Equation Modeling Approach. Behavioral Research in Accounting, 14(1), 65-86.

7. Chow, C. W., Cooper, J. C., \& Waller, W. S. (1988). Participative Bdugeting: Effects of a TruthInducing Pay Scheme and Information Asymmetry on Slack and Performance. 1The Accounting Review, 63(1), 111-122.

8. Curtis, S., \& Wright, D. (2001). Retaining Employees - The Fast Track to Commitment. Management Research News, 24(8/9), 59-64.

9. Davis, T. R. ., \& Luthans, F. (1980). A Social Learning Approach to Organizational Behavior. The Academy of Management Review, 5(2), 281-290. 
10.Dunk, A. S. (1993). The Effect of Budget Emphasis and Information Asymmetry on the Relation Between Budgetary. The Accounting Review, 68(2), 400-410.

11.Durkin, M., \& Bennett, H. (1999). Employee commitment in retail banking: identifying and exploring hidden dangers. International Journal of Bank Marketing, 17(3), 124-134.

12.Fitri, Y. (2004). Pengaruh Informasi Asimetri, Partisipasi Penganggaran Dan Komitmen Organisasi Terhadap Timbulnya Senjangan Anggaran (Studi Empiris Pada Universitas Sista di Kota Bandung). Denpasar: Simposium Nasional Akuntansi VII.

13.Freeman, R. J. (2003). Governmental and Nonprofit Organizations (7th editio.). Pearson Education, Inc.

14.Ghozali, I. (2006). Aplikasi Analisis Multivariat Dengan Program SPSS (cetakan IV.). Semarang: Badan Penerbit-UNDIP.

15.Hartmann, F. G. H., \& Moers, F. (1999). Testing contingency hypotheses in budgetary research: an evaluation of the use of moderated regression analysis \$. Accounting Organizations and Society, 24, 291315.

16.Ikhsan, A., \& Ane, L. (2007). Pengaruh Partisipasi Anggaran Terhadap Senjangan Anggaran Dengan Menggunakan Lima Variabel Pemoderasi (pp. 1-27). Makasar: Simposium Nasional Akuntansi X.

17.Julnes, P. de L., \& Holzer, M. (2001). Promoting the Utilization of Performance Measures in Public Organizations: An Empirical Study of Factors Affecting Adoption and Implementation. Public Administration Review, 61(6), 693-701.

18.Kartika, A. (2010). Pengaruh Komitmen Organisasi Dan Ketidakpastian Lingkungan Dalam Hubungan Antara Partisipasi Anggaran Dengan Senjangan Anggaran (Studi Empirik Pada Rumah Sakit Sista Di Kota Semarang). Kajian Akuntansi, 2(1), 39-60.

19.Kenis, I. (1979). Effects on Budgetary Goal Characteristic on Managerial Attitudes and Performance. The Accounting Review, 54(4), 707-721.

20.Kren, L. (1992). Budgetary Participation and Managerial Performance: The Impact of Information and Environmental Volatility. The Accounting Review, 67(3), 511-526.

21.Kren, L., Liao, \& Woody, M. (1988). Role of Accounting Information in the Control of Organizations: A Review of The Evidence. Journal of Accounting Literature, 7, 280-309.

22.Liana, L. (2009). Penggunaan MRA dengan SPSS untuk Menguji Pengaruh Variabel Moderating terhadap Hubungan antara Variabel Independen dan Variabel Dependen. Jurnal Teknologi Informasi DINAMIK, 14(2), 90-97.

23.Lukka, K. (1988). Budgetary Biasing In Organizations: Theoretical Framework And Empirical Evidence. Accounting, Organizations and Society, 13(3), 281-301.

24.Merchant, K. A. (1981). The Design of the Corporate Budgeting System: Influences on Managerial Behavior and Performance. The Accounting Review, 56(4), 813-829.

25.Merchant, K. A., \& Manzoni, J. F. (1989). The Achievability of Budget Targets in Profit Centers: A Field Study. The Accounting Review, 64(3), 539-558.

26.Milani, K. (1975). The relationship of participation in budget-setting to industrial supervisor performance and attitude: A field study. The Accounting Review, 274-284.

27.Mowday, R. T., Steers, R. M., \& Porter, L. W. (1979). The Measurement of Organizational Commitment. Journal of Vocational Behaviour, 14(2), 224-247.

28.Mulyadi. (2001). Akuntansi Manajemen: Konsep, Manfaat dan Rekayasa (3ed.). Jakarta: Salemba Empat.

29.Nouri, H., \& Parker, J. (1998). The Relationship Between Budget Participation And Job Performance: The Roles Of Budget Adequacy And Organizational Commitment. Accounting, Organizations and Society, 23(5/6), 467-483.

30.0'Reilly, C. A. I., Chatman, J., \& Caldwell, D. F. (1991). People And Organizational Culture: A Profile Comparison Approach To Assessing Person-Organization Fit. Academy of Management Journal, 34(3), 487516.

31.Oniore, Jonathan. (2014). Budgset Implementation and Economic Development in Delta-State Nigeria. International Journal of Academic Research in Business and Social Sciences, 4(3), 333-344. 
32.Onsi, M. (1973). Factor Analysis of Behavioral Variables Affecting Budgetary Slack. The Accounting Review, 535-548.

33.Owusu, Eric Edwin; Gabriel Ndomoh; Mintah Collins; Gyamfuah Yaa, Ofori Daniel. (2014). Assesing The Relationship Betweet Budget Perticipation and Employees' Performance of Public Universities in Ghana : a case of University of Education. International Journal of Academic Research in Accounting, Finance, and Management Sciences, 4(1), 85-95.

34.Pratiwi, S. H. (2011). Pengaruh Partisipasi Anggaran Terhadap Senjangan Anggaran dengan Komitmen Organisasi sebagai Variabel Moderating. INOVASI, 8(3), 102-114.

35.Quirin, J. J., Donnelly, D. P., \& O’Bryan, D. (2001). Antecedents Of Organizational Commitment: The Role Of Perception Of Equity. Advances on Accounting Behavioral Research, 4, 261-280.

36.Schiff, M., \& Lewin, A. Y. (1970). The Impact of People Budgets. 1The Accounting Review, 259-268.

37.Shields, M. D., \& Young, S. M. (1993). Antecedents and Consequences of Participative Budgeting: Evidence on the Effects of Asymmetrical Information. Journal of Management Accounting Research, 5, 265280.

38.Siegel, G., \& Marconi, H. R. (1989). Behavioral Accounting. South Western Publishing Co.

39.Subramaniam, N., \& Ashkanasy, N. M. (2001). The Effect of Organisational Culture Perceptions on the Relationship Between Budgetary Participation and Managerial Job-Related Outcomes. Australian Journal of Management, 26(1), 35-54.

40.Wiener, Y. (1982). Commitment in Organization: A Normative View. Academy of Management Review, 7(3), 418-428.

41.Windsor, C. A., \& Ashkanasy, N. M. (1995). The Effect of Client Management Bargaining Power, Moral Reasoning Development, and Belief in a Just World on Auditor Independence. Accounting Organizations and Society, 20(7), 701-720.

42.Yeo, G. B., \& Neal, A. (2004). A Multilevel Analysis of Effort, Practice, and Performance: Effects of Ability, Conscientiousness, and Goal Orientation. Journal of Applied Psychology, 89(2), 231-247.

43.Young, S. M. (1985). Participative Budgeting: The Effects of Risk Aversion and Asymmetric Information on Budgetary Slack. Journal of Accounting Research, 23(2), 829-842. 